SECTION 5. Innovative technologies in science.

Burduladze Aleksey Robizonovich

Doctor of technical Sciences, Professor

Georgian technical University, Georgia burdato@yahoo.com

Shishinashvili Manuchar Tamazovich

Doctor of engineering Sciences, Professor

Georgian technical University, Georgia m.shishinashvili@gmail.com

Magradze Manana Dimitrevna Doctor of technical Sciences, Professor Georgian technical University, Georgia mmanana0109@yahoo.com

\title{
IMPROVEMENT OF THE QUALITY OF THE ASPHALT MIX
}

Abstract: The paper studies the activating effect of tkibul sappy liptobiolits on asphalt concrete mixtures. It is shown that adding liptobiolits, due to high adhesive indicators, contributes to the improvement of physico-mechanical properties of asphalt concrete, reduces water absorption and swelling, increase specific weight and strength.

Key words: bitumen, liptobiolits, organic viscous materials.

\section{УДК 625.7/.8}

\section{УЛУЧШЕНИЕ КАЧЕСТВА АСФАЛЬТОБЕТОННОЙ СМЕСИ}

Аннотация: Изучено активирующее влияние ткибульских смоловых липтобиолитов на асфальтобетонные смеси. Показано, что добавление липтобиолитов, из-за высоких адгезионных показателей, содействует улучшению физико-механических показателей асфальтобетона, уменьшает водонасышение и набухание, увеличивает удельную массу и прочность.

Ключевье слова: битум, липтобиолит,органические вязкие материальы.

Существующее положение в области эксплуатации и строительства автомобильных дорог, сокращение сроков их службы в условиях увеличения интенсивности движения автотранспорта вынуждает основные силы и средства дорожных организаций направлять на ремонт дорожных покрытий.

Качество и долговечность дорожных асфальтобетонных покрытий в значительной степени определяются качеством битума, поскольку все свойства асфальтобетона, как термопластичного материала, определяются свойствами битума.

Установлено, что одна тонна высококачественного битума, использованного для улучшения транспортно-эксплуатационного состояния дорожного покрытия, экономит 3 т автомобильного топлива. Ежегодная экономия, получаемая за счет применения битумов повышенного качества, продления сроков службы асфальтобетонных покрытий и снижения расхода топлива может составить сотни миллионов рублей [1].

В настоящее время ощущается острый дефицит в нефтяных битумах, используемых в дорожном строительстве. Это вызывает необходимость поиска новых видов органических вязких материалов или альтернативных источников 
углеводородного сырья, пригодного для использования в виде вяжушего материала или активного компонента в битумоминеральной смеси.

С этой целью, в качестве активного компонента в асфальтобетонной смеси, нами были исследованы Ткибульские смоляные липтобиолиты. Они являются битуминозными углями, которые представлены в ткибульском угольном бассейне в виде самостоятельных пластов или включений в пластах гумусового угля.

Ввиду своеобразного вешественного состава липтобиолитовые угли по своим физико-химическим свойствам довольно резко отличаются от других углей. Органическая часть липтобиолитов содержит значительное количество кислорода, кислородсодержащих соединений серы и других активных гетероатомов, что, по всей вероятности, обуславливает их высокие адгезионные свойства. Как показали предварительные исследования, порошкообразные липтобиолиты с успехом могут служить в качестве активных добавок к стандартным минеральным порошкам из известняков. При добавлении липтобиолитов известняковый минеральный порошок приобретает гидрофобность и некоторую активность по отношению к битумам, способствуя интенсификации адсорбционных процессов. Одновременно добавление липтобиолита увеличивает объем органической субстанции в битумоминеральной смеси, что в некоторой степени обуславливает экономию битума.

Активирующая способность липтобиолитов подтверждается экспериментальными данными. Исследоания по термопластификации Ткибульских липтобиолитов показали, что растворимая в бензоле часть пластификатора характеризуется высокими кислотными и иодными числами, что свидетельствует о значительной реакционной способности составляющих компонентов. Очевидно, это и влияет на повышение адсорбционной способности битума на поверхности минерального порошка в присутствии липтобиолита.

Обогащенный липтобиолит получается при комбинированной схеме. Засслаивание фракцией осуществлялось раствором $\mathrm{ZnCl}_{2}$. Выход концентрата составлял $3 \%$ от исходного. Качественная характеристика ткибульских смоляных липтобиолитов приводится в таб. 1.

Для более наглядного положительного влияния липтобиолитов исследования проводились на минеральных порошках из низкосортных известняков Нибиского месторождения, используемых для приготовления асфальтобетонных смесей. Минеральный порошок готовился путем совместного помола липтобиолита и известняков в шаровой мелнице.

Качественная характеристика смоляных липтобиолитов

Таблица 1

\begin{tabular}{|c|c|c|c|c|c|c|c|c|}
\hline \multirow{2}{*}{ Липтобиолиты } & \multicolumn{4}{|c|}{ Технический анализ } & \multicolumn{4}{c|}{ Элементарный анализ } \\
\cline { 2 - 9 } & $\mathbf{W}^{\mathbf{a}}$ & $\mathbf{A}^{\mathbf{c}}$ & $\mathbf{V}^{\mathbf{r}}$ & $\mathbf{S}_{\mathbf{0}}^{\mathbf{c}}$ & $\mathbf{C}^{\mathbf{r}}$ & $\mathbf{H}^{\mathbf{r}}$ & $\mathbf{N}^{\mathbf{r}}$ & $(\mathbf{O + C})^{\mathbf{r}}$ \\
\hline Рядовой & 2,2 & 38,9 & 63,2 & 0,92 & 77,9 & 7,4 & 1,5 & 14,2 \\
\hline $\begin{array}{c}\text { Концентрат с уд. } \\
\text { весом 1,25 }\end{array}$ & 1,6 & 11,2 & 68,7 & 0,85 & 79,2 & 8,8 & 1,4 & 10,6 \\
\hline $\begin{array}{c}\text { Промпродукт с уд. } \\
\text { весом 1,25 }\end{array}$ & 2,3 & 43,7 & 64,1 & 0,95 & 76,1 & 6,7 & 1,6 & 14,6 \\
\hline
\end{tabular}


Средний химический состав Нибиских известняков следующий (\%): $\mathrm{CaO}-37.43-$ 45,16, $\mathrm{MgO}$ - 0.47 - 0.67, $\mathrm{Al} 2 \mathrm{O} 3$ - 1.94 3.06, Fe2O3 - 1.07 -1.54, $\mathrm{SiO} 2$ - 14.23 -24.96, $\mathrm{TiO} 2$ - 0.11-0.019, P2O5 - 0.05-0.08, K2O - 0.90-1.60; п.п.п. 29,66-34,96; влага - 1,20\%.

Для сравнительной оценки липтобиолитов были приготовлены асфальтобетонные смеси и определялись их физико-механические показатели по ГОСТу [2]. Асфальтобетонная смесь готовилась при следующем соотношении компонентов (масс. $\%$ ): битум - 4,5-5,0; минеральный порошок - 5-10; песок - 30-55; липтобиолитовый порошок - 0,1-2,5, а остальное - щебень. Испытания проводились по ГОСТу 9129-84. Были определены физико-механические показатели асфальтобетона: объемная масса, водонасыщение, набухание, прочность при сжатии цилиндров в водонасыщенном состоянии и прочность в сухом состоянии. Результаты испытании приведены в табл. 2 и на графике (рис. 1).

Таблица 2

Характеристика асфальтобетонной смеси

\begin{tabular}{|c|c|c|c|c|c|c|}
\hline № & Наименование пробы & 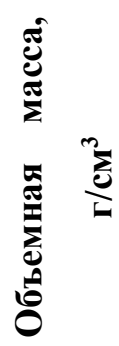 & 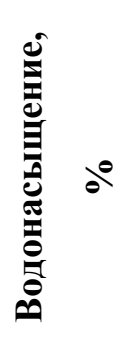 & 䜦 & 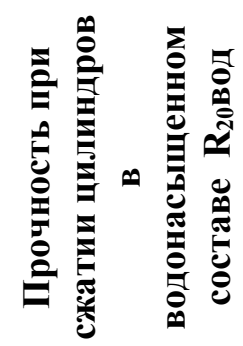 & 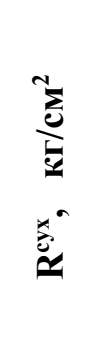 \\
\hline 1 & $\begin{array}{ll}\text { Асфальтобетон } & \text { с применением } \\
\text { минерального порошка из } \\
\text { доломитизированного известняка }\end{array}$ & 2,35 & 3,7 & 0,26 & 62 & 20 \\
\hline 2 & $\begin{array}{lr}\text { Асфальтобетон } & \text { с применением } \\
\text { минерального } & \text { порошка, } \\
\text { активированного Липтобиолитом }\end{array}$ & 2,28 & 3,2 & 0,18 & 75 & 27,1 \\
\hline
\end{tabular}

Как видно из графика, при увеличении содержания липтобиолита объемная масса уменьшается, понижаются водонасыщение и набухание, а прочность повышается. Судя по этим показателям, оптимальное содержание липтобиолита в асфальтобетонной смеси составляет около 1\%. Дальнейшее увеличение содержания липтобиолита мало отражается на изменения физико-механических показателей смеси. Эти характеристики вполне удовлетворяют требованиям ГОСТа и техническим условиям[2].

Анализируя данные экспериментальных работ и специальной литературы, можно прийти к выводу, что липтобиолитовые угли вполне пригодны в качестве активных компонентов в битумоминеральных смесях. 


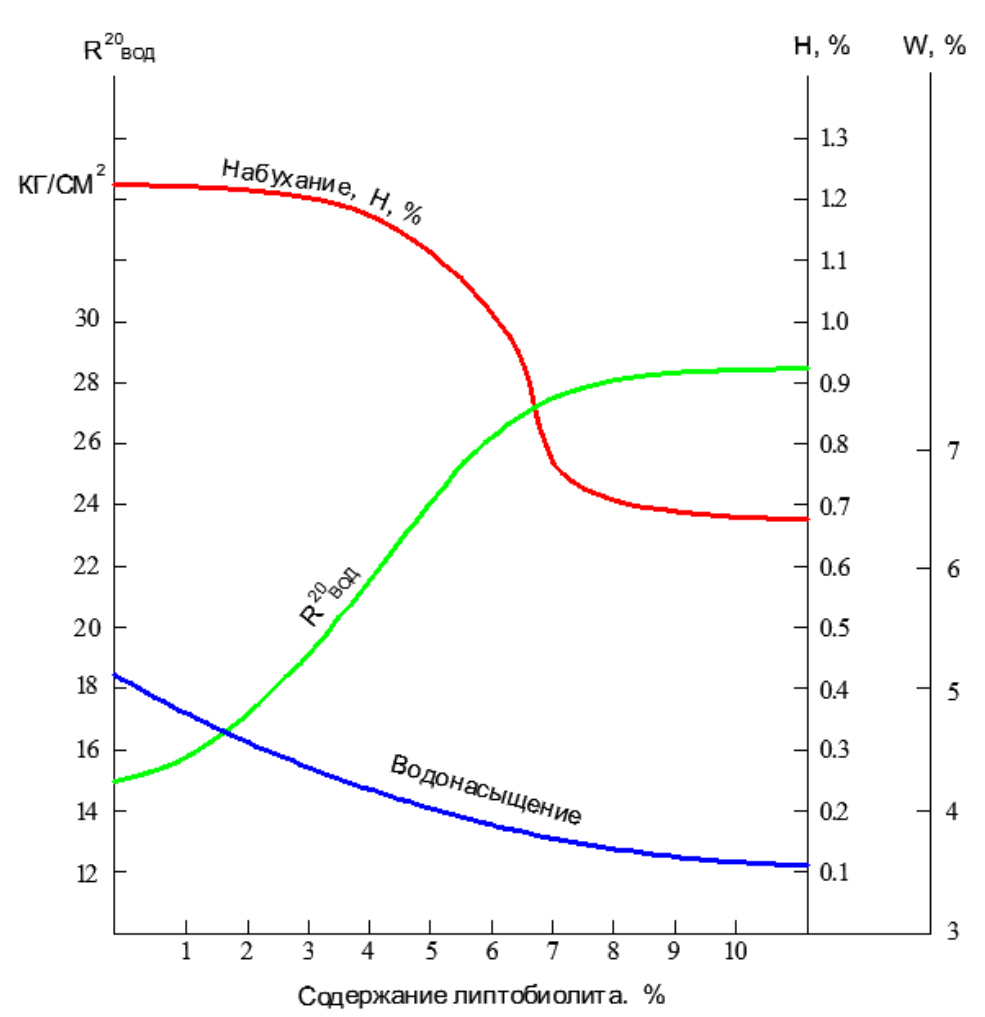

Рисунок 1 - Зависимость физико-механических характеристик асфальтобетона от содержания липтобиолита в минеральном порошке.

Принимая во внимание дефицитность нефтяных битумов, с одной стороны, и все увеличивающуся стоимость активаторов нефтяного происхождения, с другой, использование ткибульских липтобиолитов может дать определенный экономический эффект.

\section{Литература:}

1. Руденский А.В. Повышение долговечности дорожных асфальтобетонных покрытий // Сборник технической информации "Наука-московскому строительству" №4, 2007

2. ГОСТ 9128-84 Смеси асфальтобетонные дорожные, аэродромные и асфальтобетон. Технические условия.

3. D.Stall. E.Vestram, G.Zinke, Chemical thermodynamics of organic compounds [Himicheskaja termodinamika organicheskih soedinenij]. World [Mir]. M. (1971) p.475.

4. V.M.Potapov. Stereochemistry. Chemistry [Steriohimija. Himija]. M. (1988) p.535.

5. Yu.N.Panchenko, A.V.Abramov, Ch.U.Bok. Journal of Structural Chemistry [Zhurnal strukturnoj himii]. 52.48 (2011).

6. Словарь по геологии нефти и газа. - Л.: Недра, 1988. - 679 с.

7. Глущенко И.М. Теоритические основы технологии горючих ископаемых М: Металлургия, 1990. — 296 с.

8. Дракин, Л.А. Исследование фенолов генераторов смолы ткибульских смоляных липтобиолитов. - Тб., 1954. - 324с.. - Библиогр.: с. 310-323.

9. Потехин В.М., Пекаревский Б.В. Теоретические основы процессов переработки природных энергоносителей. - СПб.: СПбГТИ(ТУ), 2010 - 156с.

10. Потехин B.М., Потехин В.В. Основы теории химических процессов технологии органических веществ и нефтепереработки: Учебник для вузов. - СПб: ХИМИЗДАТ, 2005. - 912 с. 